\title{
EDITORIAL \\ El Oscar de las víctimas: \\ la ética y el espectáculo del Mal
}

\author{
Juan Jorge Michel Fariña*
}

\begin{abstract}
¿Cuál es la concepción de la ética hoy en día? Es una concepción negativa, dominada por el problema del mal y por la figura de la víctima. Auxiliar a las víctimas, asegurar los derechos del hombre contra el sufrimiento: tal es el contenido concreto de la ética. El imperativo ético se aplica teniendo como referencia el espectáculo del mal; su única función es impedir ese espectáculo.
\end{abstract}

Alain Badiou ${ }^{1}$

Una vez más la entrega de los premios Oscar de la Academia nos ha confrontado con una galería de víctimas de las violaciones a los Derechos Humanos: los abusados sexualmente por sacerdotes (Spotlight), los perseguidos por el macartismo (Trumbo), la trata y el secuestro de mujeres y niños (Room), los sobrevivientes de Auschwitz (El hijo de Saúl), los intersexuales (The Danish Girl), las lesbianas (Carol), los muertos sin sepultura (The Revenant).

$\mathrm{Y}$ en tanto espectadores no podemos sino conmovernos. Cómo no manifestar nuestra profunda empatía con el padecimiento del que han sido y son objeto los protagonistas de estas historias -cómo no llorar acompañando la jubilosa pero sufriente e incomprendida metamorfosis de Lili Elbe, retratada en las tortuosas pinturas de Gerda Wegener, en el film The Danish Girl. Pero esta sensibilidad-imprescindible para ponernos en la piel de las víctimas- no debe hacernos perder de vista la lógica que subyace a este esquema. Una lógica anticipada en el epígrafe de Alain Badiou y que Hollywood encarna con un entusiasmo preocupante.

Como lo ha dicho Julio Cabrera en un lúcido artículo, anticipatorio de la entrega del premio Oscar 2016 a mejor película en lengua no inglesa, "los norteamericanos premiaron, a lo largo de décadas, muchos filmes extranjeros que contaban historias emocionantes enfocando catástrofes sociales -especialmente el Nazismoenvolviendo niños pequeños en situaciones terribles (Fanny y Alexandre, La historia oficial, El ataque, Pelle el conquistador, Viaje de la esperanza, Indochina, Kolya,
La vida es bella, Tsotsi). Una buena receta para ganar ese Oscar es, pues, poner niños en situaciones de calamidad, como el pequeño Theeb de la película de Jordania. En ese sentido, el favorito de este año sería El hijo de Saúl, que (como El tambor, El ataque y La vida es bella) juntan Nazismo con infancia infeliz"2.

¿Significa esto que debemos permanecer insensibles frente a la poesía y el dolor que destilan esos filmes? En absoluto. Como lo dijo bellamente Alejandro Ariel, el cine es esa infinitud por donde la luz penetra para urdir en nosotros un temblor nocturno. Y somos deudores de esa experiencia éxtima. Ello nos compromete de un modo singular con la dimensión ética que emerge de esa experiencia. Pero tal dimensión no está alojada en las coordenadas del sentido común o de la opinión. La opinión, una forma de la ideología, considera elementos propios de un conjunto anticipable, que se deja aprehender por las clasificaciones existentes. El acontecimiento ético, en cambio, da cuenta de un proceso de verdad que escapa a tales clasificaciones, que en su singularidad se sitúa por fuera de lo establecido.

Solo por esta vía se podrá acceder a una concepción de la ética que no se reduzca a su expresión negativa frente al espectáculo del Mal. Ahora bien, ¿ cómo se opera en esta dirección? Ante todo, no de manera calculada. El acontecimiento ético nombra el vacío. Nombra por lo tanto lo no sabido de una situación. Por ello no puede ser calculado a priori sino a riesgo de devenir, siempre en términos de Badiou, un simulacro de verdad.

Veamos un par de ejemplos sublimes, extraídos de sendas películas cuyos actores protagónicos merecieron por ellas premios Oscar de la Academia. En La decisión de Sophie (Alan Pakula, 1982), el oficial nazi impone a Sophie una disyuntiva terrible: elegir cuál de sus dos niños deberá ser salvado, para evitar que ambos sean conducidos a la muerte. El rostro consternado de $\mathrm{Me}-$ rryl Streep -Oscar a mejor actriz por ese papel- se ha transformado en un ícono de la historia del cine. No hay

* jjmf@psi.uba.ar 
elección posible. Pero cuando no hay nada para elegir, el sujeto puede abrirse camino a partir de una decisión. Y Sophie hace la suya. Por supuesto, desconociéndose en ello. Regresará sin embargo de ese infierno para hacer síntoma del deseo que sin saberlo puso en juego en aquella noche siniestra. $Y$ es allí cuando emerge el verdadero film. O mejor: el film que permite enunciar, por fuera de toda conciencia del Mal, una verdad del sujeto.

O en The Revenant (González Iñárritu, 2015), cuando el personaje de Fitzgerald le da a Hugh Glass (Leonardo DiCaprio) la falsa oportunidad de decidir si lo remata o no en nombre del bien de los demás y de sí mismo. Como no puede hablar, basta con que consienta mediante un pestañeo... Es decir, le propone una condición en la que inevitablemente tendrá que pestañear tarde o temprano, sintiéndose así autorizado por su víctima y por lo tanto justificado por su asesinato. No hay elección posible. DiCaprio, en la piel de Glass, abre entonces hasta la desmesura sus ojos azules y los mantiene en la tensión del odio y la impotencia, hasta que finalmente, con una paz infinita los cierra para siempre. No puede saber entonces sobre el alcance de su decisión. Pero también él retornará del infierno, ahora como un revenant, para dar inicio al film, en una vertiente que, emparentada a los mitos, los sueños y la tragedia griega, suplementa la lógica del $\mathrm{Mal}^{3}$.

Son estas lecturas singulares las que hacen que un acontecimiento pueda constituirse en motor de una verdad. Están ligadas a la particularidad de una situación pero sólo por el sesgo de su vacío. No estamos ya frente a una concepción "negativa" de la ética, a una ética de la opinión consensuada que se define por oposición al Mal, sino a la que, haciendo acontecimiento, emerge como una verdad impensada del sujeto.

Por lo mismo esta verdad no alcanzará nunca potencia completa, total. Porque el sujeto resultante del proceso de una verdad no tiene poder alguno de nominación sobre todos los elementos de la situación. Es este real, este innombrable de una verdad, el que interesa sostener como horizonte de la ética.

\footnotetext{
1 Esta tesis de Alain Badiou se encuentra desarrollada en distintas conferencias dictadas por el filósofo francés, entre ellas "Etica y Psiquiatría”, pero fundamentalmente en su obra "La ética: Ensayo sobre la conciencia del mal”. Revista Acontecimiento, número 8, 1994, obra que seguiremos a lo largo de esta editorial.

2 Julio Cabrera (2016) El abrazo del Oscar. Disponible en: http://lacuevadechauvet.com/2016/02/27/el-abrazo-del-oscar/

3 Ver Michel Fariña (2016)The Revenant: Por qué retornan los fantasmas. Disponible en: http://lacuevadechauvet.com/2016/02/26/ the-revenant-por-que-retornan-los-fantasmas/
} 